\title{
THE DESIGN TECHNIQUE OF MELTING UNITS FOR PRODUCTION OF SYNTHETIC FIBROUS MATERIALS BY VERTICAL BLOWING METHOD
}

\author{
Vladislav SVIATSKII \\ Votkinsk Branch of Kalashnikov Izhevsk State Technical University \\ Pavol BOZEK \\ Slovak University of Technology \\ Mikhail SOKOLOV \\ Tambov State Technical University \\ Zygmunt $Ł U K A S Z C Z Y K$ \\ Silesian University of Technology
}

\begin{abstract}
:
This paper presents the technology of production of synthetic fibrous materials from PET-row by vertical blowing method. The formation of fibers from the melt of thermoplastics by vertical blowing method is accompanied by complex and specific phenomena, so creation of new progressive technologies, high-performance machines and units for producing such materials is impossible without process modeling, which can significantly reduce the number of natural tests, cost and development time and choose optimal operating modes. The motion of the molten material in the melting unit of the hydrostatic type is determined from the Poiseuille formula. Also in the article proved that the greatest impact on process productivity is made by the melting unit, exactly by outlet radius and the pressure change of compressed air, acting on the molten material surface. The increase in the height of the molten material column in the main cylindrical chamber of melting unit also leads to increase of process productivity.
\end{abstract}

Key words: synthetic fibrous material, PET-row, blow head, melting unit

\section{INTRODUCTION}

Synthetic fibrous materials from PET-raw materials are widely used in various fields of human activity. They are used in engineering, aircraft building, oil and gas, instrument engineering, electrical and radio engineering, electronics, construction, agriculture, medicine, sports, and household products [1, 2]. Synthetic fibrous materials possess high strength, resistance to aggressive influences, good filtering properties, low moisture absorption, they increasingly replace materials from natural fibers in the industry and make this product an attractive choice for the consumer, while creating a rich potential for a new generation of modern technical means and technologies [1]. Fibrous material products on the basis of PET-row are of double interest for national economy. The essence of such double interest consist of the fact that the use of secondary row materials can significantly reduce the prime cost of finished products, and extraction of such row materials from the environment can solve the ecological problem and prevent environmental pollution by household and industrial waste [2].

Technological process (Fig. 1) of production of synthetic fibrous materials from PET-row by vertical blowing method consists of the following stages $[3,4]$ :

1. Row material preparation. As a row material for production fibrous materials you can use, for example, primary or secondary granulated PET-material and also flexes, obtained after crushing of used plastic containers and other packing materials. The preparation of row materials means their thorough sorting - the presence of metal and other refractory items, which may cause equipment malfunction, is excluded - and thorough drying to remove moisture, which can lead to evident decrease in product quality.

2. Row material melting and obtaining a jet of molten material with specified parameters: primary diametrical size and initial flowing velocity. The melting unit can be of any type, for example, hydrostatic or extrusion, which can 
provide the processing of primary and secondary materials.

3. Fiber formation process realization by influencing the molten material jet with a stream of compressed air. The blowing device for the melt stream is a blowing head, which can be constructed for vertical and horizontal blowing of the melt jet into fiber material.

4. Preforming the given geometrical shape of the product. Regardless of the geometric shape that the finished product will have - flat napkins, sheets or pillows, the canvas is the primary product for their further formation. Such a canvas is a nonwoven fibrous product in which entangled elementary staple fibers are held together by forces of natural bonding.

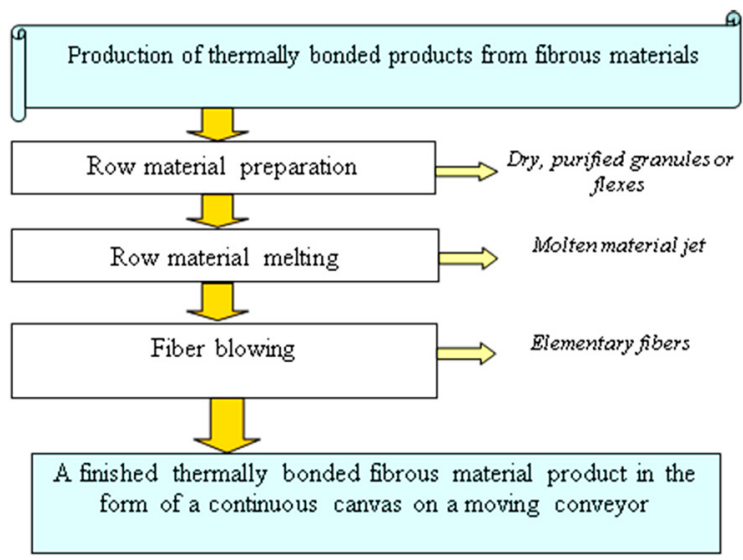

Fig. 1 Technological scheme for obtaining thermally bonded products from polymeric fibrous materials

The fourth step also involves obtaining thermally bonded canvases by braiding the elementary filaments together, which increases the strength of such thermally bonded article (canvas). The process of thermal bonding has three options:

1. By reducing the distance from the fiberizing device to the receiving conveyor, when the elementary fibers, moving together with the airflow, have not yet passed into the solid phase.

2. Heating of the fibers, for example with an electric fan, to maintain the temperature of the filaments close to the melting point at the beginning of the process of depositing them on a conveyor.

3. Calendering process. In this case, the primary canvas is passed between two cylinders heated to a temperature close to the melting temperature of the polymer. In this case, a thin layer of interconnected filaments can be obtained on the surface of the canvas.

\section{MATERIALS AND METHODS}

One of the most important tasks, when designing units for production of fibrous materials by vertical method of blowing molten material jet with the compressed air stream, is the calculation of expected process performance. In one type of these units the supply of molten polymer into the working zone of the pneumatic blow head is produced using electric melting unit, the calculation scheme of which is shown in Fig. 2 [5].

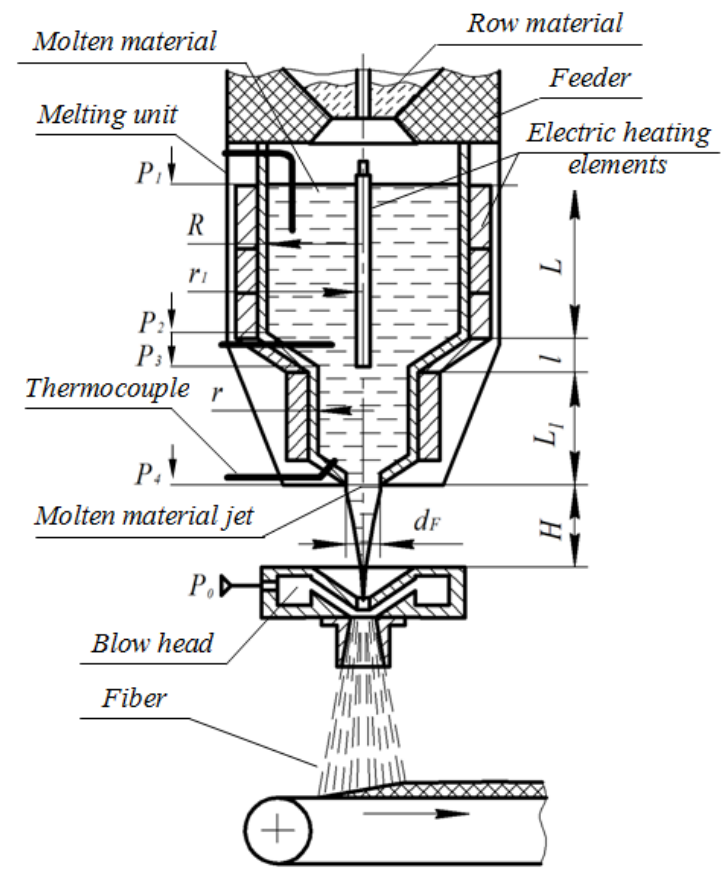

Fig. 2 The calculation scheme of melting unit for production of fiber materials from thermoplastic melt

Such construction of melting unit provides evenly staged heating and melting of row materials at a temperature of $250 . .270^{\circ} \mathrm{C}[6]$.

In contrast to the most common type of extruder units [7], the main difficulty of theoretical productivity calculation of such type of melting units consists in the fact that the working fluid is a molten thermoplastic, which can have significant unevenness of the viscosity both in height and in the radius of the inner surface. Precisely to reduce such unevenness in the design of the unit its inner surface is divided into two chambers with individual heating elements and an additional heating element is installed in the central part of the main chamber. In the design of the internal surface of the unit, smooth conic and radial transitions from one part of the surface to the other are provided, which also helps to reduce the viscosity gradient. Such a technical solution allows one to make the assumption that the molten thermoplastic is a viscous incompressible fluid. We also note that the flow of molten material, even in the smallest sections of the flow, is laminarwith very small values of the Reynolds criterion-this also simplifies the solution of the problem $[8,9]$.

Consider the motion of the molten material in each of the four geometric elements of the melting unit mentioned above. The motion of the molten material in the main cylindrical chamber can be determined from the Poiseuille formula:

$$
P_{1}=\frac{8 \mu_{1} L Q}{\pi\left(R-r_{1}\right)^{4}}
$$

where:

$\mu_{1}$ - the coefficient of dynamic viscosity of the molten thermoplastic in the first element, Pa.s;

$Q$ - volumetric flow velocity or unit capacity, $\mathrm{m}^{3} / \mathrm{s}$;

$P_{1}-$ the air pressure in the main cylindrical chamber, $\mathrm{Pa}$. 
The movement of the molten material on the second, conical portion of the melting unit inner surface is determined by the relation [9]:

$$
P_{1}+P_{2}=\left(\frac{8 \mu_{2} L Q}{3 \pi r^{4}}\right)\left(\frac{r}{R}+\left(\frac{r}{R}\right)^{2}+\left(\frac{r}{R}\right)^{3}\right)
$$

where:

$\mu_{2}$ - the coefficient of dynamic viscosity of the molten thermoplastic in the second element, $\mathrm{Pa} \cdot \mathrm{s}$;

$P_{2}=\rho g L-$ the hydrostatic pressure over the second element, $\mathrm{Pa}\left(\rho=1300 \mathrm{~kg} / \mathrm{m}^{3}\right.$ - the density of the PET, $g=9.8$ $\left.\mathrm{m} / \mathrm{s}^{2}\right)$.

The motion of the molten material on the second cylindrical section of the melting unit is also determined from the Poiseuille formula:

$$
P_{1}+P_{2}+P_{3}=\frac{8 \mu L_{1} Q}{\pi r^{4}}
$$

where:

$\mu_{3}$ - the coefficient of dynamic viscosity of the molten thermoplastic in the second cylindrical element, Pa.s;

$P_{3}=\rho g l-$ hydrostatic pressure directly above the second cylindrical element, $\mathrm{Pa}$.

The flow of a molten thermoplastic jet into the atmosphere occurs under pressure, which is determined by the expression [8]:

$$
P_{1}+P_{2}+P_{3}+P_{4}=\frac{3 Q \mu_{4}}{r_{F}^{3}}
$$

where:

$\mu_{4}$ - the dynamic viscosity coefficient of the molten thermoplastic at the jet exit into the atmosphere, $\mathrm{Pa} \cdot \mathrm{S}$;

$P_{4}=\rho g L_{1}-$ hydrostatic pressure directly above the outlet, $\mathrm{Pa}$.

Note that the coefficient of dynamic viscosity of the molten thermoplastic in different geometric elements of the internal cavity of the melting unit has a different value. In the middle part of the melting unit, it is possible to maintain the temperature of the molten material in the required range - from 270 to $280^{\circ} \mathrm{C}$ - with $\mu_{2}=\mu_{3}=190 \ldots$ $200 \mathrm{~Pa} \cdot \mathrm{s}$. In the upper part of the melting unit, where the constant loading of the feedstock takes place, the temperature on the surface of the molten material is less, so the dynamic viscosity coefficient has a larger value $\mu_{1}>\mu_{2}$. At the exit of the molten material jet into the atmosphere, it is cooled by atmospheric air, and that is intensified by interaction with the blow head, so here the dynamic viscosity coefficient also assumes a larger value $\mu_{4}>\mu_{2}$.

Considering the expressions (1), (2), (3) and (4) obtained above as a system of equations, summing up their left and right parts, after the transformations a formula for determining the volumetric productivity of the melting unit is obtained:

$$
\begin{gathered}
Q=\frac{\left(4 P_{1}+3 P_{2}+2 P_{3}+P_{4}\right)}{(A+B+C+D)} \\
A=\frac{8 \mu_{1} L}{\pi\left(R-r_{1}\right)^{4}} ; \\
B=\left(\frac{8 \mu_{2} l}{2 \pi r^{4}}\right)\left(\frac{r}{R}+\left(\frac{r}{R}\right)^{2}+\left(\frac{r}{R}\right)^{3}\right) ; \\
C=\frac{8 \mu L_{1}}{\pi r^{4}} ; D=\frac{3 \mu_{4}}{r_{F}^{3}} .
\end{gathered}
$$

Mass production capacity of the unit $G(\mathrm{~kg} / \mathrm{s})$ is determined by the formula:

$$
G=Q_{\rho}
$$

The results of the analysis of the obtained formula (6) are shown in the graphs in Fig. 3 and 4.

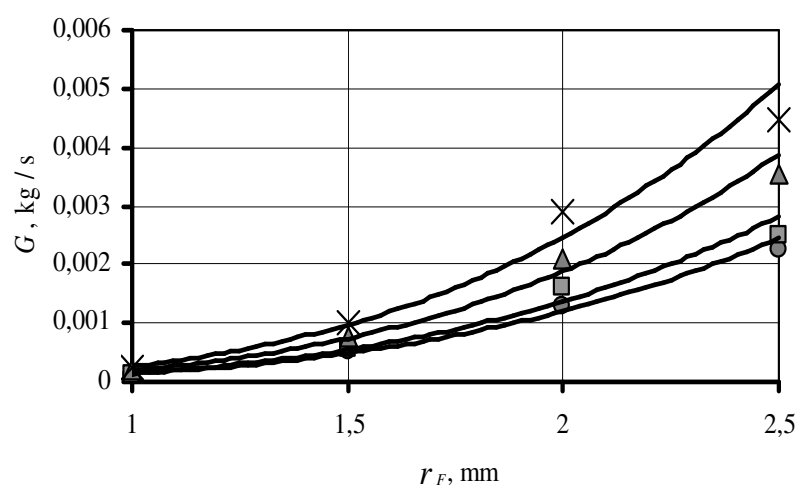

Fig. 3 The dependence of the mass productivity of the melting unit $G$ on the radius of the outlet $r_{F}$ at different air pressures $P_{1}$ $\left(x-P_{1}=20000 P a ; \Delta-P_{1}=10000 P a ; \square-P_{1}=1000 P a ; \triangle-P_{1}=O P a\right)$

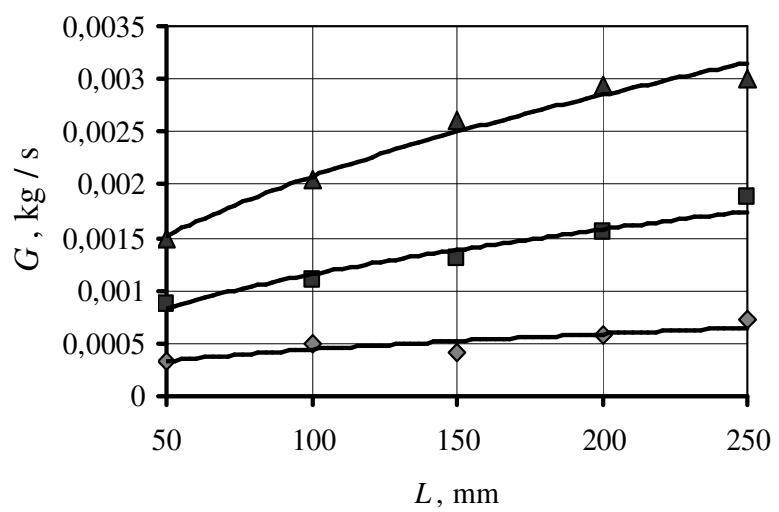

Fig. 4 Dependence of the mass productivity of the melting unit $G$ on the column height of material $L$ in the main cylindrical chamber for different values of the outlet radius $r_{F}$

$\left(\Delta-r_{F}=2.5 \mathrm{~mm} ; \square-r_{F}=2 \mathrm{~mm} ; \diamond-r_{F}=1.5 \mathrm{~mm}\right)$

\section{CONCLUSION}

Thus, the control over the performance of the melting unit is possible without changing its design parameters, but by changing the air pressure $P_{1}$ and the height of the column of molten material $L$ in the main cylindrical chamber. The presented method of calculating the melting unit productivity for the production of fibrous materials from a melt of a thermoplastic by the vertical blowing method allows us to obtain calculation formulas for melting units with an arbitrary combination and arrangement of the abovementioned basic geometric elements of its internal cavity.

Calculations showed that the greatest impact on the melting unit's output is caused by a change in the radius of the outlet $r_{F}$ and the change in the pressure of the compressed air acting on the surface of the molten material $P_{1}$. Graphs of the dependence of productivity on these parameters are shown in Fig. 3. An increase in the height of the molten material column $L$ in the main cylindrical chamber, as shown in Fig. 4, leads to a linear increase in productivity. The discrepancy between the results of the productivity calculation, according to formula (6) and the 
experimental data obtained during testing of the melting unit with the above geometric parameters of the flow section with a change in the radius of the outlet $r_{F}$ from 1.5 to $2.5 \mathrm{~mm}$ and of the pressure $P_{1}$ from zero to $20000 \mathrm{~Pa}$, doesn't exceed $8 \%$.

\section{ACKNOWLEDGMENT}

The contribution is sponsored by the project 015STU4/2018 Specialised laboratory supported by multimedia textbook for subject "Production systems design and operation" for STU Bratislava.

\section{REFERENCES}

[1] B.A. Sentyakov, K.P. Shirobokov and V.M. Svyatskiy. „Voloknistyy sorbent dla sbora nefti na osnove polietilentereftalata". Predotvrashcheniye avariy zdaniy $i$ sooruzheniy: Sbornik naucznych trudov, issue 9, pp. 631-634, 2010.

[2] V.M. Svyatskiy. Eksperimental'noye issledovaniye sorbtsionnoy sposobnosti polietilentereftalatnogo volokna pri sbore nefti s poverkhnosti vody / V.M. Svyatskiy, M.A. Svyatskiy, B.A. Sentyakov, K.A. Fonareva/ Ekologi promyshlennogo proizvodstva: Mezhotr. nauch.-prakt. zhurnal FGUP «VIMI» Moskva: 2013, Vyp. 3. pp. 53-57.

[3] V.M. Sviatskiy, B.A. Sentyakov and M.A. Sviatskiy. "Simulation of air flow rate at point of contact with a stream of melted polymeric material". Acta Tecnología, vol. 2, no. 3, pp. 1-4, 2016.

PhD., Assoc. Prof. Vladislav Sviatskii

Votkinsk Branch of Kalashnikov

Izhevsk State Technical University,

Department Technology Of Mechanical Engineering

and Instrument Making

Russia

\section{Prof. PhD., Pavol Bozek*}

Slovak University of Technology,

Faculty of Materials Science and Technology,

Institute of Applied Informatics, Automation

and Mechatronics

Slovak Republic

e-mail: pavol.bozek@stuba.sk

*correspondent author

\section{Assoc. Prof. Mikhail Sokolov}

Tambov State Technical University, Department Computer-Integrated Systems

in Mechanical Engineering

Russia

\section{dr Zygmunt Łukaszczyk}

Silesian University of Technology

Faculty of Organization and Management

Roosevelt street 26-28, 41-800 Zabrze, Poland

e-mail: zygmunt.lukaszczyk@polsl.pl
[4] V.M. Svyatskiy. Strukturnaya schema protsessa proizvodstva izdeliy iz voloknistykh materialov na osnove vtorichnogo sinteticheskogo syr'ya / V.M. Svyatskiy, B.A. Sentyakov // Avtomatizatsiya. Sovremennyye tekhnologii - Moskva: 2015, - №11. pp. 3-7.

[5] V.M. Svyatskiy. „Perspektivy proizvodstva teploizolyatsionnykh materialov na osnove polietilentereftalata" in Aktual'nyye voprosy sovremennoy techniki $i$ technologii: Sbornik dokladov Mezhdunarodnoy nauchnoy konferentsii, vol. 1. A.V. Gorbenko and S.V. Dovzhenko. Lipetsk: Izdatel'skiy tsentr "De-fakto», 2010, pp. 148-150.

[6] V.M. Svyatskiy, B.A. Sentyakov, M.A. Svyatskiy, K.B. Sentyakov and S.A. Garayev. „Modelirovaniye protcessa formoobrazovaniya kholstov iz voloknistykh materialov". Vestnik IzhGTU, no. 2, pp. 17-20, 2015.

[7] S.P. Papkov. Teoreticheskiye osnovy proizvodstva khimicheskikh volokon. Moscow: Khimiya, 1990.

[8] P.YU. Apel' and S.N. Dmitriyev. "Optimizatsiya formy por trekovykh membran. Kriticheskiye tekhnologii". Membrany, vol. 23, no. 3, pp. 32-37, 2004.

[9] G.M. Gusinskiy, Ye.B. Kremer, M.I. Kremer and B.V. Mchedlishvili. "Opredeleniye razmerov mikropor yadernykh mikrofil'trov s malym diametrom". Inzhenerno-fizicheskiy zhurnal, vol. 37, 1979. 